\title{
Genetic variability, heritability and genetic advance in Mung bean (Vigna radiata L. Wilczek) accessions
}

\author{
Itefa Degefa, Yohannes Petros \& Mebeaselassie Andargie ${ }^{\otimes}$
}

\begin{abstract}
The present study was conducted to assess the magnitude of genetic variability, heritability in broad sense and genetic advance among thirteen mung bean accessions for growth and grain yield characters. The study was conducted at the Haramaya University Rare research site and Hirna research site during the 2012/2013 cropping season. Randomized Complete Block Design with three replications was used for both locations. Each genotype was planted on a $1.2 \times 2 \mathrm{~m}$ plot consisting of four rows, which accommodates ten plants per row and thus 40 plants per plot. The result showed that number of primary branches, pods per plant, seeds per plant and harvest index had high genotypic and phenotypic coefficients of variation at both locations. For all characters, phenotypic coefficient of variation was higher than genotypic coefficient of variation indicating that there was environmental influence on these traits. The combined results for heritability showed that the high estimates of heritability and genetic advance were scored for seeds per plant and seed yield indicating that these characters were under the control of additive genetic effects. High genetic advance expected as percent of mean coupled with high heritability was observed for number of primary branches at Hirna, number of seeds per plant at Rare and number of secondary branches, pods per plant and 100seed weight for combined analysis. The present findings could be useful for establishing selection criteria for high seed yield in the mung bean breeding.
\end{abstract}

Received: 11 March 2014 / Accepted: 24 May 2014 / Published online: 9 June 2014

(c) Horizon e-Publishing Group

CITATION

Degefa, I., Petros, Y., \& Andargie, M. (2014). Genetic variability, heritability and genetic advance in Mung bean (Vigna radiata L. Wilczek) accessions. Plant Science Today, 1(2), 94-98. http://dx.doi.org/10.14719/pst.2014.1.2.54

AUTHORS' AFFILIATION

Haramaya University, College of Natural and Computational Sciences, Department of Biology, P.O. Box 217, Dire Dawa, Ethiopia.

\CORRESPONDENCE: Mebeaselassie Andargie Tel.: +251921655912. E-mail: mebhel@yahoo.com
Keywords: Genetic divergence; green gram; heritability.

\section{Introduction}

Mung bean (Vigna radiata L. Wilczek), which belongs to the angiospermic dicot family: Papilionaceae is one of the most important pulse crops in many Asian countries including India, China and Pakistan as well as many tropical and sub-tropical parts of the world since it can be grown in a wide range of environment (Wilczek, 1950; Verdcourt, 1970; Roychowdhury, Datta, Gupta, \& Tah, 2012). It occupies an important position due to its high seed protein content (about 24\%) and the ability to restore soil fertility through symbiotic nitrogen fixation (Malik, 1994; Idress, Sadiq, Hanif, Abbas, \& Haider, 2006). Mung bean is rich in essential amino acids particularly lysine, which is deficient in most of the cereal grains (Suresh, Jebaraj, Juliet, \& Theradimani, 2010).

The natural variability for yield and yield related traits is very narrow in those highly-self pollinated crops like mung bean and further selection for improvement becomes impractical due to its complex and delicate floral structure and very precise micro condition which is required for pollen dehiscence and fertilization. However, proper evaluation of the extent of genetic variation available for yield components, their heritability values and genetic advance could be of great help for the breeders in order to choose good genotypes for improvement.

Estimates of genetic parameters provide an indication of the relative importance of the various types of gene effects affecting the total variation of a plant character. Genotypic and phenotypic coefficients of variation and heritability accompanied with genetic advance are very important parameters in improving traits (Denton and Nwangburuka, 2011). Jonson, Robinson, \& Comstock (1955) reported the immense importance of selecting and evaluating varieties for quantitative and yield ability in any breeding programme, before such varieties can be introduced to a given local environment. Previous studies 
(Khan, Qureshi, Hussain, \& Ibrahim, 2005; Srivastava and Singh, 2012; Gadakh, Dethe, \& Kathale, 2013) showed that significant differences were observed among various genotypes through genetic variability and correlation studies between yield and yield components in mung bean and chickpea.

Therefore, the present study was conducted to assess genetic variability, heritability and genetic advance among the thirteen mung bean accessions at two different agro-ecological locations in order to select the appropriate accession(s) that are suited to Ethiopian environment.

\section{Materials and methods}

\section{Experimental site}

The field experiment was carried out at two sites, Haramaya University Rare research site and Hirna research site in Ethiopia during the main rainy season from June to September 2012. The Haramaya University

Table 1. Estimates of error mean square, genetic components of variance, heritability and genetic advance of mung bean evaluated at Hirna research site

\begin{tabular}{ccccccccc}
\hline Traits & $\boldsymbol{\sigma}^{\mathbf{2}}$ & $\boldsymbol{\sigma}^{\mathbf{2}} \mathbf{g}$ & $\boldsymbol{\sigma}^{\mathbf{2}} \mathbf{p}$ & $\mathbf{P C V}(\mathbf{\%})$ & $\mathbf{G C V}(\mathbf{\%})$ & $\mathbf{H ~ ( \% )}$ & GA & GAM (\%) \\
\hline NPB & 0.12 & 2.06 & 2.17 & 38.20 & 37.19 & 94.93 & 2.86 & 74.50 \\
NSB & 0.29 & 2.28 & 2.57 & 32.48 & 30.60 & 88.71 & 2.92 & 59.28 \\
PH & 2.58 & 27.37 & 87.29 & 17.77 & 9.95 & 31.35 & 6.03 & 11.48 \\
PPP & 45.48 & 185.00 & 230.00 & 43.00 & 38.50 & 80.40 & 25.13 & 71.14 \\
SPP & 5416.18 & 570.00 & 5986.00 & 23.43 & 7.22 & 9.52 & 14.28 & 4.32 \\
BMYP & 1016.00 & 1768.00 & 2784.00 & 30.25 & 24.11 & 63.50 & 69.00 & 39.58 \\
SPPD & 0.86 & 3.95 & 4.80 & 24.18 & 21.93 & 82.29 & 3.70 & 40.87 \\
DF & 1.47 & 26.40 & 28.14 & 10.00 & 9.69 & 93.80 & 10.24 & 19.32 \\
DM & 1.84 & 156.00 & 157.80 & 13.05 & 12.99 & 98.85 & 25.50 & 26.32 \\
HSW & 0.15 & 1.07 & 1.21 & 26.55 & 24.86 & 87.89 & 1.89 & 45.66 \\
HI & 0.01 & 0.01 & 0.02 & 29.48 & 21.84 & 54.54 & 0.15 & 32.72 \\
PL & 0.32 & 2.18 & 4.18 & 24.19 & 17.49 & 52.15 & 2.19 & 25.98 \\
YLD & 16245.70 & 38874.70 & 55120.40 & 28.78 & 24.17 & 70.52 & 341.00 & 41.82 \\
\hline
\end{tabular}

Where, NPB: Number of primary branches, NSB: Number of secondary branches, PH: Plant height, PPP: Pods per plant, SPP: Seeds per plant, BMYP: Biomass yield, SPPD: Seeds per pod, DF: Days to flowering, DM: Days to maturity, HSW: 100 seed weight, HI: Harvest index, PL: Pod length, YLD: Seed yield in $\mathrm{kg} / \mathrm{ha}, \sigma^{2}$ e: environmental, $\sigma^{2} \mathrm{~g}$ : genotypic and $\sigma^{2}$ : phenotypic variance, PCV: phenotypic and GCV: genotypic coefficient of variation, H\%: heritability, GA: genetic advance and GAM; genetic advance as percent of mean.

Table 2. Estimates of error mean square, genetic components of variance, heritability and genetic advance of mung bean evaluated at Rare research site

\begin{tabular}{ccccccccc}
\hline Traits & $\boldsymbol{\sigma}^{\mathbf{2}} \mathbf{e}$ & $\boldsymbol{\sigma}^{\mathbf{2}} \mathbf{p}$ & $\boldsymbol{\sigma}^{\mathbf{2}} \mathbf{g}$ & $\mathbf{P C V}(\%)$ & $\mathbf{G C V}(\%)$ & H (\%) & GA & GAM (\%) \\
\hline NPB & 2.26 & 2.64 & 0.74 & 42.17 & 24.92 & 27.84 & 0.93 & 27.02 \\
NSB & 0.43 & 1.19 & 0.77 & 30.00 & 24.18 & 64.53 & 1.45 & 39.90 \\
PH & 29.26 & 54.21 & 24.95 & 20.98 & 14.23 & 46.02 & 6.97 & 19.88 \\
PPP & 87.48 & 143.16 & 55.68 & 56.18 & 35.09 & 38.895 & 9.58 & 45.00 \\
SPP & 8628.85 & 8669.85 & 6204.60 & 48.28 & 40.95 & 71.40 & 137.20 & 71.32 \\
BMYP & 710.16 & 2130.00 & 1420.28 & 37.95 & 30.99 & 66.66 & 63.33 & 52.00 \\
SPPD & 2.32 & 5.13 & 2.75 & 28.92 & 21.19 & 53.60 & 2.49 & 31.90 \\
DF & 2.27 & 17.40 & 15.14 & 7.70 & 7.189 & 87.00 & 8.26 & 15.27 \\
DM & 3.32 & 152.36 & 149.00 & 12.86 & 12.73 & 97.79 & 24.85 & 25.91 \\
HSW & 0.18 & 1.15 & 0.97 & 25.17 & 23.11 & 84.20 & 1.86 & 43.64 \\
HI & 0.01 & 0.01 & 0.01 & 36.04 & 30.14 & 69.60 & 0.16 & 51.60 \\
PL & 0.47 & 3.38 & 2.91 & 24.48 & 22.74 & 86.09 & 3.22 & 42.99 \\
YLD & 9619.00 & 21692.50 & 12073.66 & 27.47 & 20.50 & 55.65 & 166.60 & 31.13 \\
\hline
\end{tabular}

Where, NPB: Number of primary branches, NSB: Number of secondary branches, PH: Plant height, PPP: Pods per plant, SPP: Seeds per plant, BMYP: Biomass yield, SPPD: Seeds per pod, DF: Days to flowering, DM: Days to maturity, HSW: 100 seed weight, HI: Harvest index, PL: Pod length, YLD: Seed yield in $\mathrm{kg} / \mathrm{ha}, \sigma^{2} \mathrm{e}$ : environmental, $\sigma^{2} \mathrm{~g}$ : genotypic and $\sigma^{2}$ p: phenotypic variance, PCV: phenotypic and GCV: genotypic coefficient of variation, H\%: heritability, GA: genetic advance and GAM; genetic advance as percent of mean. 
Table 3. Estimates of error mean square, genetic components of variance, heritability and genetic advance of mung bean of the two sites combined

\begin{tabular}{ccccccccc}
\hline Traits & $\boldsymbol{\sigma}^{\mathbf{2}} \mathbf{c}$ & $\boldsymbol{\sigma}^{\mathbf{2}} \mathbf{p}$ & $\boldsymbol{\sigma}^{\mathbf{2}} \mathbf{g}$ & $\mathbf{P C V}(\mathbf{\%})$ & $\mathbf{G C V}(\mathbf{\%})$ & $\mathbf{H ~ ( \% )}$ & GA & $\begin{array}{c}\text { GAM } \\
\mathbf{( \% )}\end{array}$ \\
\hline NPB & 1.19 & 2.55 & 1.37 & 43.74 & 32.00 & 53.56 & 1.75 & 48.00 \\
NSB & 0.37 & 1.81 & 1.44 & 31.43 & 28.69 & 79.65 & 2.28 & 51.48 \\
PH & 16.20 & 38.95 & 22.75 & 14.25 & 10.90 & 58.40 & 7.50 & 17.14 \\
PPP & 66.63 & 159.50 & 92.89 & 44.60 & 34.06 & 58.22 & 15.00 & 53.50 \\
SPP & 702.25 & 1748.00 & 1046.00 & 16.02 & 12.39 & 59.80 & 51.46 & 19.70 \\
BMYP & 892.64 & 1607.00 & 715.00 & 26.00 & 17.69 & 44.49 & 38.70 & 24.16 \\
SPPD & 1.58 & 5.01 & 3.43 & 26.54 & 21.95 & 68.46 & 3.14 & 37.31 \\
DF & 2.01 & 21.79 & 19.79 & 8.70 & 8.30 & 90.80 & 3.12 & 5.83 \\
DM & 42.50 & 169.50 & 127.00 & 13.64 & 11.80 & 74.92 & 20.00 & 21.00 \\
HSW & 0.23 & 1.23 & 1.00 & 26.67 & 24.08 & 81.47 & 2.28 & 54.94 \\
HI & 0.01 & 0.11 & 0.11 & 94.67 & 92.89 & 97.24 & 0.07 & 17.63 \\
PL & 0.39 & 2.77 & 2.38 & 20.86 & 19.31 & 85.92 & 2.93 & 36.79 \\
YLD & 12932.00 & 35008.00 & 22076.00 & 27.68 & 21.98 & 63.05 & 243.05 & 35.96 \\
\hline
\end{tabular}

Where, NPB: Number of primary branches, NSB: Number of secondary branches, PH: Plant height, PPP: Pods per plant, SPP: Seeds per plant, BMYP: Biomass yield, SPPD: Seeds per pod, DF: Days to flowering, DM: Days to maturity, HSW: 100 seed weight, HI: Harvest index, PL: Pod length, YLD: Seed yield in $\mathrm{kg} / \mathrm{ha}, \sigma^{2} \mathrm{e}$ : environmental, $\sigma^{2}$ g: genotypic and $\sigma^{2}$ : phenotypic variance, PCV: phenotypic and GCV: genotypic coefficient of variation, $\mathrm{H} \%$ : heritability, GA: genetic advance and GAM; genetic advance as percent of mean.

Rare research site is found at an altitude of $1950 \mathrm{~m}$ and has an average annual rainfall of about $790 \mathrm{~mm}$ (Belay, Wortman, \& Hoogen, 1998) whereas the Hirna research site is found at an altitude of $1870 \mathrm{~m}$ above sea level and it receives mean annual rainfall of 990-1100 $\mathrm{mm}$ (Solomon, 2006).

\section{Materials and field trial}

For this study thirteen mung bean (Vigna radiata.L) accessions were used. These accessions were obtained from Melkassa Agricultural Research Center (MARC). Randomized Complete Block Design (RCBD) with three replications was used for both locations. Each genotype was planted on a $1.2 \times 2 \mathrm{~m}$ plot consisting of four rows, which accommodates ten plants per row and thus 40 plants per plot. A distance of $1 \mathrm{~m}$ was maintained between the plots. Row to row spacing was $40 \mathrm{~cm}$ and plant to plant spacing was $20 \mathrm{~cm}$. The weeding activities were carried out after two to three weeks from sowing and no fertilizer was applied.

\section{Data collection and analysis}

The pre and post harvesting observations were recorded as the means from five randomly selected plants from each genotype in each replication for all characters studied except days to flowering and days to maturity, viz., days to $50 \%$ flowering, days to maturity, 100 seed weight (g), biomass yield per plant (g), seed yield ( $\mathrm{kg} / \mathrm{ha}$ ), number of seeds/pod, plant height $(\mathrm{cm})$, harvest index, number of primary and secondary branches/plant, number of pods/plant, number of seeds/plant, pod length $(\mathrm{cm})$, which were determined on plot basis according to Moussa, Millan, Moreno, \& Gil (2000).
The data collected for each quantitative trait mentioned above were subjected to analysis of variance (ANOVA) (Gomez and Gomez, 1984) using SAS computer software program (SAS, 2002, Version 9.0). Homogenity test for the error variance was done before computing the analysis of variance. For significant difference among the treatments, mean separation was carried out using Duncan multiple range test (DMRT) at 5\% levels of significance. In addition, the phenotypic, genotypic and environmental variances and coefficient of variation were estimated according to the methods suggested by Burton and Devane (1953) whereas estimation of heritability and estimation of expected genetic advance were computed using the formula adopted by Allard (1960) and Jonson et al. (1955) respectively.

\section{Results and discussion \\ Variance components and coefficients of variation}

Estimates of phenotypic, genotypic and environmental variances and phenotypic and genotypic coefficients of variation are given in Table 1 for Hirna, Table 2 for Rare and Table 3 for combined analysis of the two locations. At Hirna, magnitude of phenotypic and genotypic coefficient of variation were observed to be highest for pods per plant (43\% and 38.5\%) respectively whereas at Rare, highest phenotypic coefficient of variation was $56.18 \%$ for pods per plant, and highest genotypic coefficient of variation was $40.95 \%$ for seeds per plant. When the data of the two locations analyzed simultaneously, harvest index showed $94.67 \%$ and $82.89 \%$ for phenotypic and genotypic coefficient of variation respectively (Table 3).

However, days to flowering (10\%) and seeds per plant 
(7.22\%) were accompanied with the relatively very low PCV and GCV respectively at Hirna whereas at Rare, days to flowering had the lowest PCV (7.7\%) and GCV (7.19) respectively. The same is true for a combined analysis where PCV and GCV values were lowest (8.7\% and 8.3\%) for days to flowering respectively. Generally, in this study, for all traits the values of phenotypic variance $(\sigma 2 p)$ exceeded that of genotypic variance $(\sigma 2 \mathrm{~g})$, though the difference is small. This indicates that environmental variance $(\sigma 2 \mathrm{e})$ had its own contribution on the performance of the traits in addition to genotypic variance. Similarly Gadakh et al. (2013) and Byregowada, Chandraprakash, \& Jagadeesh (1997) reported that the magnitude of PCV and GCV was the highest for seed yield followed by pods per plant and pods per cluster in green gram. Natarajan, Thiyagarajan, \& Rathnaswamy (1988) also reported that pods and seeds per plant have the prominent grain yield determinants in mung bean.

Genetic coefficient of variation together with heritability estimates would give the best indication of the amount of gain due to selection (Siddique and Gupta, 1991). Therefore, there could be better chance for improvement of the above traits with the relatively highest value of genotypic coefficient of variation.

\section{Heritability and genetic advance}

Estimate of heritability for the traits under study is given in Table 1 and 2 for Hirna and Rare respectively. The magnitude of the estimated broad sense heritability in this study ranged from $9.52 \%$ for seeds per plant to $98.85 \%$ for days to maturity in Hirna while it ranged from $27.84 \%$ for number of primary branches to $97.79 \%$ for days to maturity at Rare. The existence of relatively high heritability in a given trait indicates the presence of more additive gene effects for possible improvement (Sabu, Abdullah, Lim, \& Wickneswari, 2009). Generally, moderately high heritability was coupled with relatively high genetic coefficient of variation for almost all traits except for days to flowering in a combined analysis.

From the result it is possible to conclude that the variability in this study was mainly due to genotypic variance though there is a small contribution from the environmental variance on the performance of the traits. Genetic coefficient of variation together with heritability estimates would give the best indication of the amount of gain due to selection. Therefore, there could be a better chance for improvement of the above traits with the relatively highest value of genotypic coefficient of variation.

Heritability estimates are classified as low (5-10\%), medium (11-30\%), high (31-70\%) and the highest for the value greater than this (Dabholkar, 1992). An estimate of heritability is essential for applying optimum breeding strategy. In this study, traits like numbers of primary branches, seeds per plant, numbers of secondary branches, pods per plant, seeds per pod, harvesting index, days to flowering, days to maturity, hundred seed weight, pod length and seed yield in $\mathrm{kg} / \mathrm{ha}$ had very high heritability. Similarly high heritability value on hundred seed weight, days to maturity and days to flowering was reported by Ilhamuddin, Tajamumal, \& Inayastullah (1989) on mung bean. In the study carried out on mung bean by Sarwar, Sadiq, Saleem, \& Abbas (2004) heritability estimates were high for pods per plant, hundred seed weight and seed yield per plant. The characters which exhibited high heritability suggests that the selection will be more effective whereas the characters showing low heritability indicates that the selection will be effected by the environmental factors. Generally, for traits having highest phenotypic heritability value which is close to 1 show a good index of genotypic merit, so genetic gain can be made easily through selection (Johnson and Frey, 1967; Adhikari and Pandey, 1982). Therefore heritability determines the effectiveness of selection, though the effectiveness of selection for a given trait depending on relative importance of both genetic and environmental factors in the expression of phenotypic differences among genotypes in a population.

The magnitude of genetic advance, at 5\% selection intensity, along with the corresponding genetic advance as percent of mean was estimated and presented in Table 1, 2 and 3 for Hirna, Rare and combined for both sites respectively. There was relatively high genetic advance for such traits as seed yield in $\mathrm{kg} / \mathrm{ha}$, pods per plant and days to maturity at Hirna whereas at Rare, seeds per plant, seed yield in $\mathrm{kg} / \mathrm{ha}$ and biomass yield showed a relatively high genetic advance. For the two sites (combined), genetic advance was the highest for seeds per plant, biomass yield and for seed yield in $\mathrm{kg} / \mathrm{ha}$. Therefore, selection based on these traits could predict the performance of the progenies.

High heritability estimates along with high genetic advance is usually more helpful in predicting gain under selection than heritability estimates alone (Arora, 1991). The present study revealed that high heritability coupled with high expected genetic advance for seeds per plant $(60$ and 52), biomass yield (45 and 39) and seed yield in $\mathrm{kg} / \mathrm{ha}$ (63 and 243) for the two sites in a combined analysis.

A relatively high genetic advance was obtained for seed yield per plant, pods per plant and biomass yield per plot in chick pea, which partially supports the result of our study by Adhikari and Pandey (1982) as well as Arora (1991). Malik, Hussain, Haqqani, \& Chaudhry (1983) also reported high heritability coupled with high genetic advance for seed per plant and number of pods in mung bean indicating that these traits were controlled by additive genes and can easily be transferred to succeeding generations. But, relatively low genetic advance was 
observed for number of primary branches (1.75), number of secondary branches (2.28), 100 seed weight (2.28), and pod length (2.93). This low estimate of genetic advance arises from low estimate of phenotypic variance or it is observed as a result of non-additive gene action which may be epistatic and/or dominance effects.

Generally, the results of this study showed that characters like seeds per plant, seed yield in $\mathrm{kg} / \mathrm{ha}$ and biomass yield showed high heritability and high genetic advance and will be effective for selection as compared to selection of number of primary branches, 100 seed weight, number of secondary branches and days to maturity in mung bean improvement programme involving these accessions.

\section{Acknowledgments}

We would like to express our gratitude to Ministry of Education of Ethiopia for providing funding for this research work. Our deep gratitude goes to Melkassa Agricultural Research Center (MARC) for supplying the mung bean seeds.

\section{References}

Adhikari, G., \& Pandey, M. P. (1982). Genetic variability in some quantitative characters and scope for improvement in chickpea. International Chickpea Newsletter, 7, 4-5.

Allard, R. W. (1960). Principle of plant breeding. New York: John Wiley and sons, Inc.

Arora, P. P. (1991). Genetic variability and its relevance in chickpea. International Chickpea Newsletter, 25, 9-10.

Belay, S., Wortman, C.W., \& Hoogen, G. (1998). Haricot bean agro-ecology in Ethiopia: definition using agro-climatic and crop growth stimulation models. African Crop Science Journal, 6, 9-18.

Burton, G.W., \& Devane, E. H. (1953). Estimating heritability in Tall Fescue (Festuca arundinacea) from replicated clonal material. Agronomy Journal, 45, 487-488, http://dx.doi.org/10.2134/agronj1953.000219620045001000 $05 \mathrm{x}$

Byregowada, M., Chandraprakash, J., \& Jagadeesh, C. S. (1997). Genetic variability and interrelationships among yield and yield components in green gram (Vigna radiata (L.) Wilezek). Crop Research, 13, 361-368.

Dabholkar, A. R. (1992). Elements of Biometrical Genetics. New Delhi, India: Concept Publishing Company. PMCid:PMC1519597

Denton, O. A., \& Nwangburuka, C. C. (2011). Heritability, genetic advance and character association in six related characters of Solanum anguivi. Asian Journal of Agricultural Research, 5, 201-207. http://dx.doi.org/10.3923/ajar.2011.201.207

Gadakh, S. S., Dethe, A. M., \& Kathale, M. N. (2013). Genetic variability, correlations and path analysis studies on yield and its components in mungbean (Vigna radiata (L.) Wilczek) Bioinfolet, 10 (2a), 441-447.

Gomez, K. A., \& Gomez, A. A. (1984). Statistical procedure for Agricultural research (2nd Ed.) USA: John Willey and Sons, Inc.

Idress, A., Sadiq, M. S., Hanif, M., Abbas, G., \& Haider, S. (2006). Genetic parameters and path-coefficient analysis in mutated generation of Mungbean Vigna radiata L. Wilczek. Journal of Agricultural Research, 44 (3), 181-189.
Ilhamuddin, M. A., Tajamumal, M., \& Inayastullah, D. (1989). Genotypic and phenotypic variability in yield and other quantitative character in mungbean (Vigna radiata (L.) Wilczek). Sar. Agric., 5, 69-71.

Johnson, G. R., \& Frey, K. J. (1967). Heritabilities of quantitative attributes of oats (Avena sp.) at varying levels of environmental stress. Crop Science, 7, 43-46. http://dx.doi.org/10.2135/cropsci1967.0011183X000700010 016x

Jonson, H. W., Robinson, H. F., \& Comstock, R. E. (1955). Estimates of genetic and environmental variability in soybean. Agronomy Journal, 47(7), 314-318. http://dx.doi.org/10.2134/agronj1955.00021962004700070009x

Khan, M. R., Qureshi, A. S., Hussain, S. A., \& Ibrahim, M. (2005). Genetic variability induced by gamma radiation and its modulation with gibberellic acid in $\mathrm{M}_{2}$ generation of chickpea (Cicer arietinum L.). Pakistan Journal of Botany, 37(2), 285-292.

Malik, B. A. (1994). Grain legumes. In: Nazir MS (Ed). Crop Production. (p. 301). National Book.

Malik, B. A., Hussain, S. H., Haqqani, A. M., \& Chaudhry, A. H. (1983). Genetic variability in mungbean (Vigna radiata L). Pakistan Journal of Agriculture Research, 4(3), 171-173.

Moussa, E. H., Millan, T., Moreno, M. T., \& Gil, J. (2000). Genetic analysis of seed size, plant height, day to flower and seed per plant by using both morphological and molecular markers in chickpea. Journal of Genetics and Breeding, 54, 101-107.

Natarajan, C., Thiyagarajan, K., \& Rathnaswamy, R. (1988). Association and genetic diversity studies in green gram (Vigna radiata (L.) Wilczek). The Madras Agricultural Journal, 75, 238-245.

Roychowdhury, R., Datta, S., Gupta, P., \& Tah, J. (2012). Analysis of Genetic Parameters on Mutant Populations of Mungbean (Vigna radiata L.) after Ethyl Methane Sulphonate Treatment Notulae Scientia Biologicae, 4(1), 137-143.

Sabu K. K., Abdullah M. Z., Lim L. S., \& Wickneswari R. (2009). Analysis of heritability and environmental variances in a rice cross. Agronomy Research, 7, 97-102.

Sarwar, G., Sadiq, M. S., Saleem, M., \& Abbas, G. (2004). Selection criteria in $\mathrm{F}_{3}$ and $\mathrm{F}_{4}$ population of mung bean (Vigna radiata $\mathrm{L}$. Wilczek). Pakistan Journal of Botany, 36(2), 297-310.

Siddique, A., \& Gupta, S. N. (1991). Genetic and phenotypic variability for seed yield and other traits in cowpea (Vigna unguiculata $\mathrm{L}$. Walp). International Journal of Tropical Agricultural, 9, 144-148.

Solomon, A. (2006). Genotype $\mathrm{x}$ environment interaction and correlation among some stability parameters of yield and its attributes in maize (Zea mays L). M.Sc. Thesis, School of Graduate Studies of Haramaya University, Ethiopia.

Srivastava, R. L., \& Singh, G. (2012). Genetic variability, correlation and path analysis in Mungbean (Vigna radiata (L.)Wilczek) Indian Journal of Life Sciences, 2(1), 61-65.

Suresh, S., Jebaraj, S., Juliet, H. S., \& Theradimani, M. (2010). Genetic studies in mungbean (Vigna radiata (L). Wilczek). Electronic Journal of Plant Breeding, 1(6), 1480-1482.

Verdcourt, B. (1970). Studies in the Leguminosae-Papilionoideae for the "Flora of Tropical East. Africa": IV. Kew Bulletin, 24, 507-569. http://dx.doi.org/10.2307/4102859

Wilczek, R. Vigna. (1954). In: Fiore du Congo Beige, 6, 343-393.

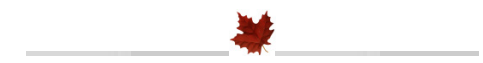

